\title{
Comparison of methods used to capture herpetofauna: an example from the Carnarvon basin
}

\author{
J.K Rolfe and N.L. McKenzie \\ Department of Conservation and Land Management, PO Box 51, \\ Wanneroo, Western Australia 6065, Australia
}

\begin{abstract}
We used a combination of pitfall-trapping and hand-foraging methods to sample the frog and reptile species on 63 quadrats in the southern Carnarvon Basin of Western Australia. The quadrats were positioned to represent the geographical extent and diversity of terrestrial environments in the $75000 \mathrm{~km}^{2}$ study area.

We compared the three types of pit-traps that systematically captured species: fenced tubes ( $125 \mathrm{~mm}$ diameter and $550 \mathrm{~mm}$ deep), fenced buckets (300 mm diameter $\times 450 \mathrm{~mm}$ deep) and unfenced invertebrate-pits (300 $\mathrm{mm} \times$ $450 \mathrm{~mm}$, containing glycol and covered by a sheet of wire mesh with square $10 \mathrm{~mm} \times 10 \mathrm{~mm}$ holes). The buckets contributed only $5(0.12 \%)$ of the 820 quadrat-species intersections derived from the trapping programme. After standardising for differences in the number of trap-nights, the average tube caught 1.33 times more reptiles than the average bucket.

We compared the classification structure derived from the entire datamatrix with that from a reduced matrix, which excluded difficult-to-sample taxa as well as data derived by hand-foraging. We could have ignored handforaging as a sampling technique, as well as the snake, pygopid and varanid components of the fauna, without changing the patterns in species composition revealed by the analysis, or reducing its ecological discrimination.
\end{abstract}

\section{INTRODUCTION}

Considerable time and money was spent sampling herpetofauna during the survey of nonaquatic environments of the Irwin-Carnarvon study area (McKenzie et al., 2000). This study explores the relative effort-effectiveness of the various trapping methods used, of trapping versus hand-foraging, and of including all components of the herpetofauna in the sampling programme.

In particular, we investigate the contributions that hand-foraging, and the inclusion of the 'difficult-tosample' taxa in the sampling programme, made to the analysis outcome in McKenzie et al. (2000).

\section{METHODS}

The Irwin-Carnarvon Study Area encompassed $75000 \mathrm{~km}^{2}$. Herpetofauna were sampled on 63 quadrats positioned throughout the geographical extent of the study area in a stratified random array - in typical examples of each of the surface stratigraphic units that characterise the study area. Each quadrat was $400 \times 400 \mathrm{~m}$, and 2 to 6 quadrats were clustered around each of 13 survey areas, herein referred to as 'campsites'.

Two pitfall-trap arrays were placed on each quadrat. Each array comprised a line of six PVC tubular pitfall-traps ('tubes'), $125 \mathrm{~mm}$ in diameter and $500 \mathrm{~mm}$ deep, spaced at $10 \mathrm{~m}$ intervals along a $50 \mathrm{~m}$ flywire drift fence that was $300 \mathrm{~mm}$ high. About five $\mathrm{m}$ from either side of the $50 \mathrm{~m}$ fence was a 'bucket' pitfall-trap $300 \mathrm{~mm}$ in diameter and 450 $\mathrm{mm}$ deep positioned at the centre of a $10 \mathrm{~m}$ long drift fence. In addition, 30 plastic 'tubs', 150x150x200 mm deep, were scattered across each quadrat during the Autumn (May) 1995 survey. The tubs were sunk into the ground around the periphery of grass tussocks, and in the leaf litter under trees and shrubs.

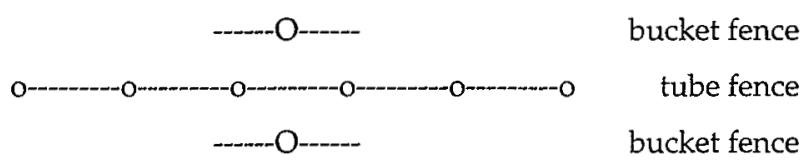

Survey effort is summarised in Table 1. McKenzie et al. (2000) provide details of the timing of sampling sessions on the quadrats. We estimate that a total of 691 person-hours was spent on the trapping programme (approximately 2 personhours per quadrat per session to install and close the drift-fence arrays, and 0.3 hours per quadrat per day to check them). In comparison, a total of 702 person-hours were spent foraging. Except for the first day (when the pitfall-trap arrays were being established), a minimum of one person-hour per day per quadrat was spent foraging for herpetofauna during each sampling session, mainly 
Table 1 Herpetofaunal survey effort per sampling session, excluding the 9260 tub-nights in May 1995 (160 personhours to install and check).

\begin{tabular}{lllllll}
\hline & Oct94 & Jan95 & May95 & Nov95 & Mar96 & Total \\
\hline Number of quadrats & 61 & 2 & 63 & $23^{\mathrm{a}}$ & 61 & - \\
Average number of days/quadrat & 5 & 3.5 & 5 & 1.87 & 3.72 & - \\
Person-hours spent foraging & 244 & 5 & 252 & $36^{\mathrm{a}}$ & 165 & 702 \\
Person-hours spent trapping & 214 & 7 & 221 & 59 & 190 & $691^{\mathrm{b}}$ \\
Bucket-nights & 1220 & 12 & 1244 & - & - & 2476 \\
Tube-nights & 3660 & 72 & 3704 & 516 & 2736 & 10688 \\
Total trap-nights & 4880 & 84 & 4948 & 516 & 2736 & 13164 \\
\hline
\end{tabular}

a see McKenzie et al. (2000)

${ }^{b}$ plus 400 hours for invertebrate pits and 160 hours for tubs.

by visual searching, stripping dead bark, turning logs, raking leaf litter, and digging. The staff involved all had prior experience in herpetofaunal surveys. Because the hand-foraging and pitfalltrapping programmes were carried out concurrently, time spent travelling between the quadrats and the campsites is ignored in these calculations.

Reptiles and frogs were also caught in the five pitfall-traps set for invertebrates on each quadrat, and left open for 12 months (114000 trap nights). Each trap was $300 \mathrm{~mm}$ in diameter and $450 \mathrm{~mm}$ deep. Unlike the vertebrate pitfall-traps, each of the invertebrate pits was partially filled with a solution of glycol-formalin (see Harvey et al., 2000), unfenced, and covered by a sheet of wire mesh (10 mm square holes) designed to minimise accidental vertebrate deaths. They took an additional 300-400 person-hours to install and check.

To compare the two main pit-trap types used to capture herptofauna (tubes and buckets), we scaled the number of captures of each species in each traptype according to the ratio of tube : bucket trapnights. For each herptofaunal family, we then carried out a 'Students t-test' to test the null- hypothesis that capture rates were no different.

To determine whether the hand-foraging programme, in combination with the difficult-tosample taxa (snakes, pygopodids and varanids), influenced the analysis outcomes, we compiled a 'species-x-quadrat' matrix based solely on the frog, gecko, dragon and skink trapping records (presence/absence data). We also excluded the species-records that were not assigned to a collection method ("not specified" in Table 2). Next. we defined classification partitions in the matrix using the same clustering algorithms as McKenzie et al. (2000) used to partition the entire herpetofaunal matrix. Finally, the two partitions were compared using a modification by Hubert and Arabie (1985) of the statistic by Rand (1971).

Species names suffixed with 'A' or ' $B$ ' indicate related, but undescribed, taxa (see Aplin et al., in press).

\section{RESULTS}

Appendix 1 lists the methods by which the frog and reptile species were captured. It is summarised in Table 2.

Table 2 Number of specimens (and species) of each herpetofaunal group captured by each method. Total trapping effort is listed in terms of trap-nights.

\begin{tabular}{lllllllll}
\hline & Tubes & Buckets & $\begin{array}{l}\text { Tubes plus } \\
\text { Buckets* }^{*}\end{array}$ & Tubs & Invert. Pits & Foraging & $\begin{array}{l}\text { Not } \\
\text { Specified }\end{array}$ & $\begin{array}{l}\text { Total } \\
\text { Species }\end{array}$ \\
\hline Frogs & $98(9)$ & $1(1)$ & $99(9)$ & $2(2)$ & $150(11)$ & $5(4)$ & $10(3)$ & $\mathbf{1 2}$ \\
Geckos & $415(15)$ & $50(14)$ & $564(15)$ & $15(5)$ & $135(15)$ & $310(14)$ & $27(7)$ & $\mathbf{1 7}$ \\
Pygopodids & $15(6)$ & $2(2)$ & $18(7)$ & 0 & $3(2)$ & $15(6)$ & 0 & $\mathbf{1 0}$ \\
Dragons & $258(14)$ & $75(12)$ & $357(15)$ & $45(9)$ & $85(9)$ & $176(15)$ & $22(6)$ & $\mathbf{1 6}$ \\
Skinks & $441(37)$ & $83(29)$ & $628(43)$ & $101(22)$ & $1055(42)$ & $749(39)$ & $106(25)$ & $\mathbf{5 8}$ \\
Varanids & $43(4)$ & $7(3)$ & $58(4)$ & $1(1)$ & $3(2)$ & $16(3)$ & $1(1)$ & $\mathbf{4}$ \\
Snakes & $15(6)$ & $6(4)$ & $28(7)$ & 0 & $31(6)$ & $51(14)$ & $3(2)$ & $\mathbf{1 6}$ \\
Totals & $1285(91)$ & $224(65)$ & $1752(100)$ & $164(39)$ & $1462(87)$ & $1322(95)$ & $169(44)$ & 133 \\
Trap-nights & 10688 & 2476 & 13164 & 9450 & 114000 & & & \\
\hline
\end{tabular}

* The sum of 'Tubes' + 'Buckets' is usually less than the value in the column headed "Tubes plus Buckets"; one of the three field teams did not distinguish between tube- and bucket-captures during the first sampling session, and there were occasional lapses by others. 


\section{The Various Pitfall-trapping Methods}

Allowing for the 4.3:1 ratio in tubes:buckets within the vertebrate trap arrays (10 688:2476, from Table 2), the tubes were more effective than the buckets in capturing frogs (22.7 times more individual frogs were captured in the average tube), geckos (x 1.9 more), pygopodids ( $x$ 1.7), skinks ( $x$ $1.2)$ and varanids ( $x 1.4)$, but buckets were better for dragons ( $x$ 1.3) and snakes ( $x$ 1.7). Overall, the average tube-night caught 1.33 times more reptiles and frogs than the average bucket-night (Students$\mathrm{t}=-2.43$, p. $=0.02$ ).

A species-by-species comparison didn't reveal many strong biases in capture-rates after correcting Appendix 1 for differences in trapping effort:

- 14 species were caught more often in tubes by a factor of three or more (Arenophryne rotunda, Cyclorana maini, Litoria rubella, Neobatrachus wilsmorei, Diplodactylus pulcher, Gehyra variegata, Nephrurus levis, Rhynchoedura ornata, Lerista uniduo, L. muelleriA, Ctenotus schomburgkii, C. iapetus, C. hanloni $\mathrm{A}$ and C. hanloniB), and

- 5 species favoured buckets by a factor of three or more (Ctenophorus femoralis, Lerista elegans, $L$. planiventralis planiventralis, Menetia greyii $\mathrm{B}$ and Demansia calodera).

The five invertebrate pitfall-traps set on each quadrat for one year (circa 114000 trap-nights) yeilded a total of 150 frog and 1312 reptile specimens (11 frog and 76 reptile species). In comparison, 99 frog and 1653 reptile specimens ( 9 frog and 91 reptile species) were captured on the same set of quadrats by the vertebrate traps (excluding tub captures) with $11 \%$ of the trappingeffort (13 164 tube+bucket nights). Overall, the invertebrate traps were less effective than the vertebrate trap arrays. Even so, they added an average of $1.5+/-0.2$ (s.e.), $n=63$, species to each quadrat list. Considering that $16.3+/-0.7$ (s.e.) species were recorded on the average quadrat (McKenzie et al., 2000), this was a $9.2 \%$ improvement.

Relatively few species were captured more commonly in invertebrate traps than in the vertebrate trap arrays (Appendix 1), and nearly all of those were small, suggesting that the relative inefficiency of the invertebrate traps was exacerbated by the mesh filters (as we intended). For instance, Arenophryne rotunda (110 from invertebrate pits : 28 from vertebrate trap arrays) and Uperoleia russelli (6:0) are the smallest of the study area's frogs (snout-vent length less than 33 $\mathrm{mm})$. Similarly, Lerista planiventralis decora (10:1), L. bipes (7:0), L. elegans (159:32), L. gascoynensis (10:0), L. humphriesi (4:0), L. kendricki (18:3), L. lineopunctulataA (30:9), Menetia greyii (45:18), $M$. greyiiB (46:9) and $M$. greyiiC (5:0) are amongst the smallest skinks. Considering their relatively large mass, Ctenotus severus (5:0) and Rhamphotyphlops grypusA (11:2) were exceptions. In terms of their body diameter however, all of these species could pass through the $10 \mathrm{~mm}$ holes in the wire mesh that covered the invertebrate pits. The larger species captured by the invertebrate traps were represented by small individuals (sub-adults), or had forced their way past the edge of the wire mesh. After allowing for the difference in trapping effort (9:1), no frog or reptile species was captured more efficiently by the invertebrate traps.

Because the tubs were used only in May 1995, we can make no valid comparison with tubes, buckets or invertebrate pits. However, considering how little time was needed to install and check them over the sampling session (2.5 person-hours per quadrat) compared to the 4 hours per quadrat spent on hand-foraging, the tubs yielded a surprisingly high return in small Ctenotus and Lerista species, and in sub-adult dragons (Appendix 1).

Overall, the vertebrate buckets added only 5 quadrat-species intersections ( 7 specimens) to the tube captures, and one intersection to the combined 'tube + invertebrate-pit' captures (the term 'quadrat-species intersections' is defined in Table 3). This was only $0.5 \%$ and $0.1 \%$ of total trapping intersections, respectively (Table 3 ).

Table 3 Number of quadrat-species intersections* added by hand-foraging compared with trapping.

\begin{tabular}{lcccc}
\hline & $\begin{array}{c}\text { Both trapped } \\
\text { and foraged }\end{array}$ & $\begin{array}{c}\text { Trapped } \\
\text { only }\end{array}$ & $\begin{array}{c}\text { Foraged } \\
\text { only (\%) }\end{array}$ & Total \\
\hline Frogs & 3 & $43^{*}$ & $1(2)$ & 47 \\
Geckos & 77 & 136 & $41(16)$ & 254 \\
Dragons & 63 & 61 & $23(16)$ & $\mathbf{1 4 7}$ \\
Skinks & 159 & 181 & $86(20)$ & 426 \\
Varanids & 4 & 31 & $11(24)$ & 46 \\
Pygopodids & 2 & 17 & $13(41)$ & 32 \\
Snakes & 9 & 34 & $30(41)$ & 73 \\
TOTAL & 317 & 503 & 205 & 1025 \\
\hline
\end{tabular}

* There were 43 events where a frog species was caught in a quadrat by trapping only ( 4 species of frog at one quadrat, 3 at another, 2 at 13 others, and 1 at 10 others $=43$ ). 
ASSEMBLAGE_I

Ctenotus saxatilis

Notoscincus ornatus ornatus

Lerista kennedyensis

Lerista muelleric

Ctenotus calurus

Ctenotus hanloniB

Ctenotus pantherinus

Ctenophorus rubens $\mathrm{B}$

Ctenotus iapetus + marion

Ctenophorus clayi

Menetia greyiic

Ctenotus rufescens

Menetia surda cresswelli

Lerista bipes

Ctenophorus femorali

Cyclodomorphus melanops melan.

Cyclorana platycephalus

ASSEMBLAGE_2

rotunda

pinigerus spinig.

Lerista planiventralis decora

Ctenotus australis

umphriesi

Neobatrachus pelobatoides

Crenadactylus aff. 'ocellatus Ctenotus alleni

Menetia surda subsp. indet.

Ctenophorus maculatus maculat.

Lerista kendricki

tenophorus maculatus badius

Lerista elagans

Morethia lineoocellata

Lexista planiventralis planiv.

Ctenotus fallens

Cyclodomorphus celatus

Diplodactylus alboguttatus

Lerista lineopunctulata

Lerista praepeditaA

Diplodactylus ornatus

Menetia 'amaura'

Lerista praepedita

Lerista varia

Ctentus hanlonid

Ctenotus hanlon id

Lerista haroldi

Ctenophorus rubensa

Strophurus rankin

Tympanocryptis parviceps
BBWPMBBBBWMMWMMMNWNANNNWW GGGGG KKMMMM BCN P KKK BBBCCCCCEEZZPPPNNN ZZZ BOOEDOOOOODDODDRAOEEEEEO JJJJJ EERRRR BUA E EEE BBBUUUUULLUUEEEAAA UUU 152431342412545123123451123541225343111345254234561221253345345

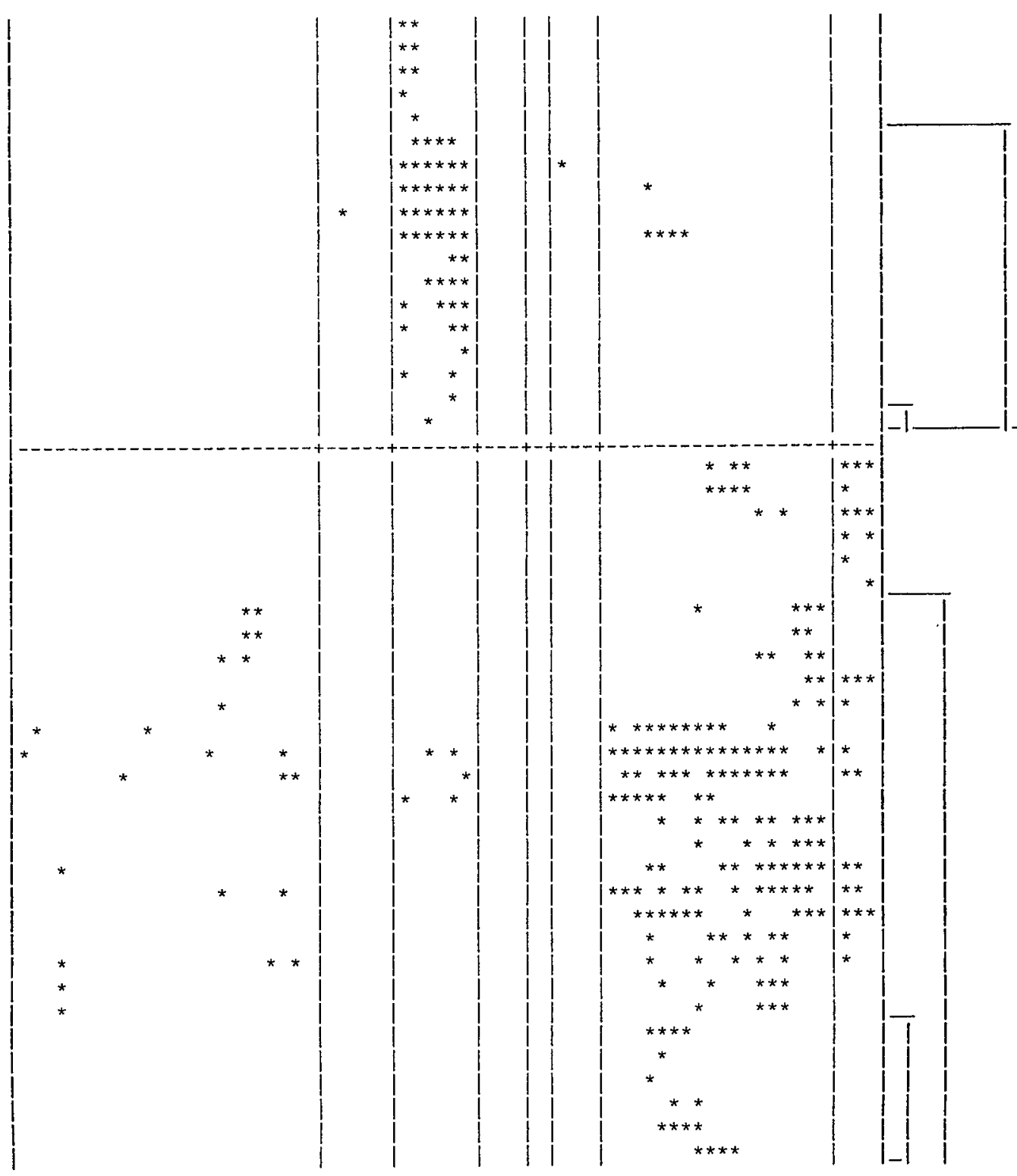


Neobatrachus wilsmorei

Ctenophorus reticulatus

Diplodactylus squarros
Rhymchoedura ornata

Rhynchoedura ornata

Ctenotus schomburgki

Diplodactylus klugei

Diplodactylus stensicillatu

Eremiascincus fasciolatus

Ctenophorus scutulatus

Lerista connivens

Heteronotia binoei

Menetia greyiid

Moloch horridus

Diplodactylus pulcher

Lerista macropisthopus

Gehyra variegata

Lerista muelleriB

Lerista uniduo

Nephrurus levis

Pogona minor

Ctenotus severus

Litoria rubella

Uperoleia russelli

Neobatrachus aquilonius

Lerista gascoynensis

Neobatrachus fulvus

Lerista muelleria

Cyclorana maini

Limnodynastes spenceri
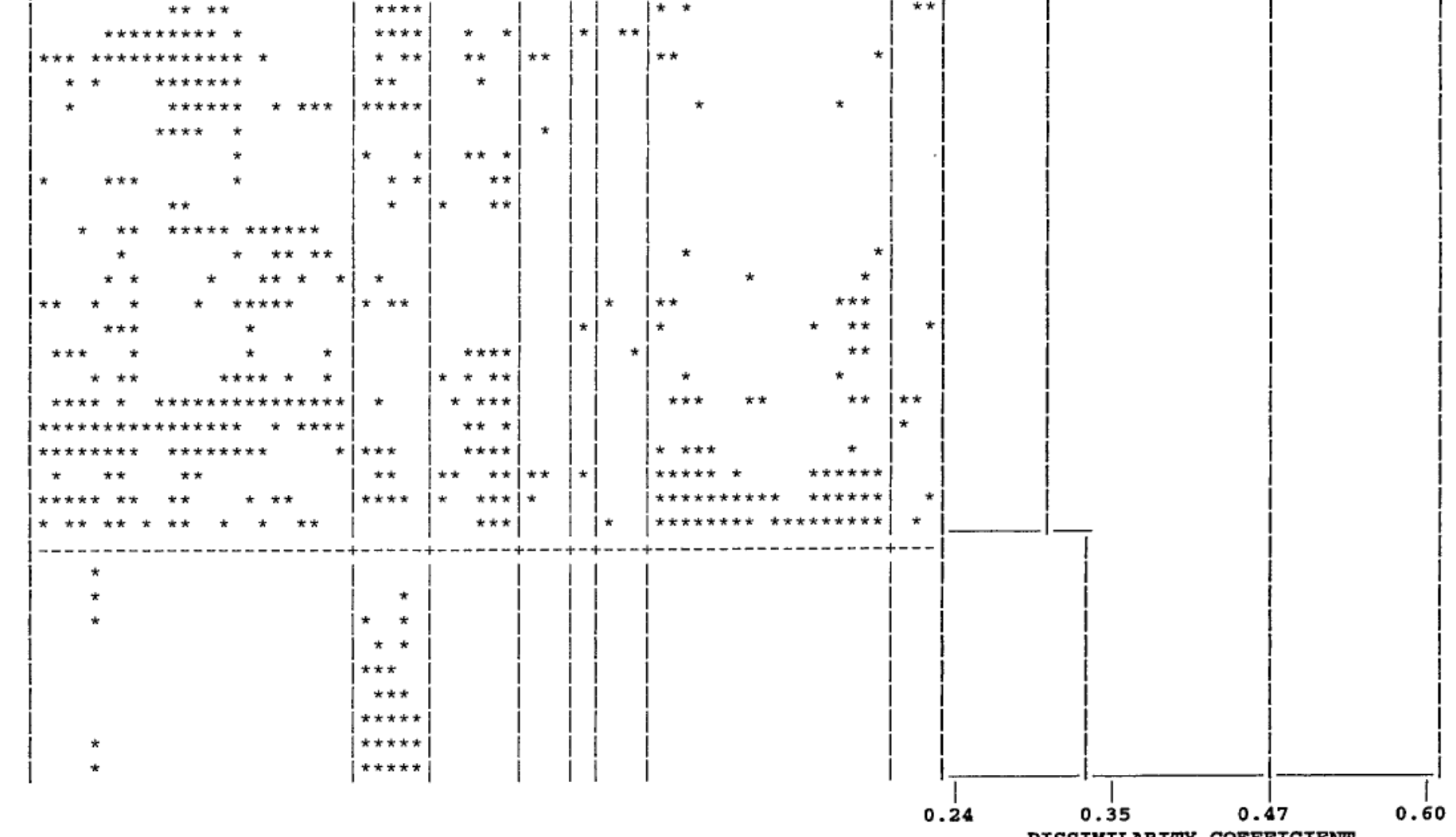

Figure 1 Matrix of frog, gecko, dragon and skink trap-records re-ordered according to species co-occurrences at the same quadrats and similarities in the overall species composition of the quadrats. Quadrat codes are printed vertically. The species dendrogram is included to indicate classification structure down to the 10 group level. To save space, Diplodactylus aff. alboguttatus has been abbreviated to Diplodactylus aff. albogut. 


\section{Hand-foraging}

A detailed examination of Appendix 1 revealed that the 702 hours spent on hand-foraging by the survey personnel added only 17 species to the 116 species derived from the overall trapping program (13\% of the 133 species total), and most of those were snakes or pygopodids: no dragons, no varanids, no frogs, two geckos ( $12 \%$ of 17 species), five skinks (9\%), two pygopodids $(20 \%)$ and nine snakes $(50 \%)$.

In terms of the species-lists from each quadrat individually (quadrat-species intersections as defined in Table 3), hand-foraging added only small proportions of frogs, geckos, dragons and skinks, but larger proportions of snakes, pygopodids and varanids (Table 3 ).

\section{Effect of Eliminating Snakes, Pygopodids and Varanids Recorded by Hand-foraging}

Figure 1 is the matrix of frog, gecko, dragon and skink records collected from the various pitfall traps. The species have been re-ordered according to similarities in their co-occurrences at the same quadrats, and the quadrats re-ordered in terms of similarities in their species composition, using the numerical clustering procedures applied by McKenzie et al. (2000).

Four discrete species assemblages and eight quadrat groups are apparent, and have been delineated in Figure 1. The same numbers of classification partitions were identified when the entire herpetofaunal data-base was analysed (see Figure 3 in McKenzie et al. 2000). The two

Table 4 Comparison between the classification partition derived from the entire data-matrix (Partition-1, see Figure 3 in McKenzie et al., 2000 ) and the partition derived from a matrix that excluded hand-foraged records, snakes, varanids and pygopodids (Partition-2, see Figure 1 herein). For instance, group-1 in both classifications had 20 quadrats in common.

\section{(a) Quadrat Groups}

Partition-1

$\begin{array}{lllllllll} & \mathbf{1} & \mathbf{2} & \mathbf{3} & \mathbf{4} & \mathbf{5} & \mathbf{6} & \mathbf{7} & \mathbf{8} \\ \mathbf{1} & 20 & 0 & 0 & 0 & 0 & 0 & 0 & 0 \\ \mathbf{2} & 1 & 5 & 0 & 0 & 0 & 0 & 0 & 0 \\ \mathbf{3} & 0 & 0 & 6 & 0 & 0 & 0 & 0 & 0 \\ \mathbf{4} & 0 & 0 & 0 & 3 & 0 & 0 & 0 & 0 \\ \mathbf{5} & 0 & 0 & 0 & 0 & 1 & 0 & 0 & 0 \\ \mathbf{6} & 0 & 0 & 0 & 0 & 0 & 3 & 0 & 0 \\ \mathbf{7} & 3 & 0 & 0 & 0 & 0 & 0 & 14 & 0 \\ \mathbf{8} & 0 & 0 & 0 & 0 & 0 & 0 & 4 & 3\end{array}$

(b) Species Assemblages

Partition-1

\section{Partition-2}

$\begin{array}{lllll} & \mathbf{1} & \mathbf{2} & \mathbf{3} & \mathbf{4} \\ \mathbf{1} & 19 & \mathbf{1} & 0 & 0 \\ \mathbf{3} & 0 & 29 & 0 & 0 \\ \mathbf{4} & 0 & \mathbf{1} & 34 & 0 \\ & 0 & 0 & \mathbf{1} & 8\end{array}$

classifications are compared quantitatively in Table 4 using a modification by Hubert and Arabie (1985) of the statistic of Rand (1971). The statistic for the quadrat partitions was 0.7020 (diagonal/total $=55$ / $63=0.8730$ ), and for species assemblage partitions was 0.9127 (diagonal $/$ total $=90 / 93=0.9677$ ). The eight quadrats and three species assigned to different clusters by the two analyses are indicated in bold in Figure 1. Even the distributions of data points and the classification structures inside the species- and the quadrat-partitions defined in the two figures are similar. We concluded that the data collected by hand-foraging, and the inclusion of the difficult-to-sample taxa (snakes, pygopodids and varanids), had little effect on the analysis results.

\section{DISCUSSION}

The 1.33: 1 difference between tube and bucket specimen capture-rates in the fenced vertebrate trapping arrays may have been caused either by differences in trap design or by predation:

- The six tubes in each array were connected by their $50 \mathrm{~m}$ fence, so an animal that turned and followed the fence away from four of these tubes might be caught by an adjacent tube. In contrast, each of the buckets was centrally located along its own $10 \mathrm{~m}$ fence, so an animal that followed the fence in the wrong direction would not be captured. On the other hand, a resident animal might encounter the fence on several occasions before capture, and each bucket had a proportionally longer fence $(10 \mathrm{~m})$ than each tube (50/6 $=8.3 \mathrm{~m}$ on average). We also note that the two bucket-fences straddled the tube-fence in each vertebrate trap array, effectively reducing the effectiveness of the central section of the tube-fence.

- Hopping mice can remove smaller animals from tubes and buckets, while foxes, cats, snakes and large varanids steal from buckets. Tracks of these species were sometimes observed along the drift-fences, and capture-rates at the NA quadrats in May 1995 improved after we began to check the vertebrate buckets late in the evening as well as in the morning.

Although hand-foraging involved approximately one third of the total sampling effort (in personhours, see Table 1), it added only 17 species (13\%) to the combined trapping result (Appendix 1), and 11 of these 17 were snakes or pygopodids. In contrast, trapping added 38 species to the foraging result, and only seven of these were pygopodids or snakes. Quadrat-species intersections (Table 3) provided a more sensitive comparison between hand-foraging and trapping, and yielded a similar result.

Snakes, varanids and pygopodids are often eliminated from quantitative analyses of quadrat 
data because they occur in low densities and are poorly sampled by our quadrat-based sampling designs (How, in review; McKenzie et al., 1989). In the Carnarvon study area we detected $94 \%$ of the previously known dragon species, $85 \%$ of the geckoes, $80 \%$ of the varanids, $79 \%$ of the skinks, $77 \%$ of the pygopodids, $73 \%$ of the frogs, and $65 \%$ of the snakes (McKenzie et al., 2000). Although the snake and pygopodid inventories of the quadrats are likely to be too unreliable for quantitative analysis, the gecko and frog percentages are probably under-estimated because the three gecko species and two of the four frogs that were overlooked have geographical ranges that barely intrude into our study area.

The possibility that trapping would have been sufficient without hand-foraging was confirmed by our final analysis. This showed that the classification structures derived from a matrix of frog, gecko, dragon and skink trap-records (Figure 1) were virtually identical to the structures derived from the total data-set (Figure 3 in McKenzie et al., 2000). Pragmatically, snakes, pygopodids and varanids could have been ignored, and the labourintensive hand-foraging methods deleted, without sacrificing biogeographical discrimination or changing the outcomes of the study.

\section{ACKNOWLEDGEMENTS}

Ken Aplin, Phillip Boglio, A.A. Burbidge, A.H. Burbidge, Mark Cowan, Anthony Desmond, P.J. Fuller, Nich Hall, R.E. Johnstone, Bradley Marion, W.P. Muir, R. Smith, L.A. Smith and P. Stone assisted in the sampling program.

Funding was provided by the Commonwealth through the National Reserve System Co-operative Program of the Australian Nature Conservation Agency (now Environment Australia), together with funds provided by the Western Australian Department of Conservation and Land Management and the Western Australian Museum.

\section{REFERENCES}

Aplin, K.P., Adams, M. and Cowan, M.A. (in press). Systematics and biogeography of the herpetofauna of the Carnarvon region of Western Australia. Records of the Western Australian Museum Supplement.

Harvey, M.S., Sampey, A., West, P.L.J. and Waldock, J.M. (2000). Araneomorph spiders from the southern Carnarvon Basin, Western Australia: a consideration of regional biogeographic relationships. Records of the Western Australian Museum Supplement No. 61: 295321.

Hobbs, T.J., Morton, S.R., Masters, P. and Jones, K.R. (1994). Influence of pit-trap design on sampling of reptiles in arid spinifex grasslands. Wildlife Research 21: 483-490.

How, R.A. (1998). Long-term sampling of an herpetofaunal assemblage on an isolated bushland remnant. Journal of the Royal Society of Western Australia 81: 143-148.

Hubert, L. and Arabie, P. (1985). Comparing partitions. Journal of Classification 2: 193-218.

McKenzie, N.L., Belbin, L., Margules, C.R. and Keighery, G.J. (1989). Selecting representative reserve systems in remote areas: a case study in the Nullarbor region, Australia. Biological Conservation 50: 239-261.

McKenzie, N.L., Rolfe, J.K., Aplin, K., Cowan, M. and Smith, L.A. (2000). Herpetofauna of the southern Carnarvon Basin, Western Australia. Records of the Western Australian Museum Supplement No. 61: 335360.

Rand, W.M. (1971). Objective criteria for the evaluation of clustering methods. Journal of the American Statistical Association 66: 846-850.

Manuscript received 21 April 1998; accepted 13 March 1999. 


\section{APPENDIX 1}

Numbers of frogs and reptiles captured by various methods.

\begin{tabular}{|c|c|c|c|c|c|}
\hline Species & Tube & Bucket & $\begin{array}{l}\text { Tube or } \\
\text { Bucket* }\end{array}$ & Tub & $\begin{array}{l}\text { Inver } \\
\text { Pit }\end{array}$ \\
\hline & \multicolumn{5}{|c|}{ FROGS } \\
\hline Arenophryne rotunda & 27 & 1 & & 1 & 110 \\
\hline Cyclorana maini & 25 & & & & \\
\hline \multicolumn{6}{|l|}{ C. platycephalus } \\
\hline Limnodynastes spenceri & 5 & & & & 17 \\
\hline Litoria rubella & 9 & & & & \\
\hline Neobatrachus pelobatoides & 1 & & & & \\
\hline N. aquilonius & 4 & & & & \\
\hline N. fulvus & 5 & & & & \\
\hline N. sutor & 1 & & & & \\
\hline N. wilsmorei & 21 & & & 1 & \\
\hline \multicolumn{6}{|l|}{ Pseudophryne guentheri } \\
\hline Uperoleia russelli & & & & & \\
\hline
\end{tabular}

Crenadactylus aff. 'ocellatus'

GECKOS

Diplodactylus alboguttatus

D. stenodactylus

D. conspicillatus

D. klugei

D. ornatus

D. pulcher

D. squarrosus

Strophurus michaelseni

S. rankini

S. spinigerus spinigerus

S. strophurus

Gehyra punctata

G. variegata

Heteronotia binoei

Neprurus levis

Rhynchoedura ornata

$$
4
$$$$
3
$$$$
3
$$$$
5
$$$$
1
$$$$
1
$$$$
14
$$

Aprasia sp. aff. fusca

A. haroldi

A. smithi

Delma australis

D. butleri

D. nasuta

Lialis burtonis

Pletholax gracilis edelensis

Pygopus lepidopodus

$P$. nigriceps

Amphibolurus longirostris

Ctenophorus caudicinctus

C. clayi

C. femoralis

C. nuchalis

C. maculatus badius

C. maculatus maculatus

C. reticulatus

C. rubensA

C. rubens B

C. scutulatus

Diporiphora winneckei

Moloch horridus

Pogona minor

Rankinia adelaidensis adelaid.

Tymanocryptis parviceps

1

Invert Foraging Not Specified

Totals

10
4
2
17
3
1
2
2
2
1
6

1

1

2
1

3

(2)

1

1

4

1

2

\section{PYGOPODIDS}

(1)

1


Tube or Tub

Invert Foraging

Not

Totals Bucket Specified

Cryptoblepharus carnabyi

SKINKS

C. plagiocephalus

Ctenotus alleni

C. australis

C. calurus

C. fallens

C. hanloniA

C. hanloniB

C. iapetus + marioni Pit

C. mimetes

C. pantherinus

C. rufescens

C. saxatilis

C. schomburgkii

C. severus

C. uber

Cyclodomorphus celatus

C. melanops melanops

Egernia depressa

E. stokesii badia

Eremiascincus fasciolatus

Lerista bipes

L. connivens

L. elegans

L. gascoynensis

L. haroldi

L. humphriesi

L. kendricki

L. petersoni

L. kennedyensis

L. lineata

L. lineopunctulataA

L. macropisthopus

L. muelleriA

L. muelleriB

L. muelleriC

L. muelleriD

L. planiventralis decora

L. planiventralis planiventralis

L. praepedita $\mathrm{A}$

L. praepeditaB

L. uniduo

L. varia

Menetia 'amaura'

M. greyiiA

$M$. greyii B

M. greyiiC

$M$. surda cresswelli

M. surda subsp. indet.

Morethia butleri

M. lineoocellata

M. obscura

M. ruficauda exquisita

Notoscincus ornatus ornatus

Tiliqua multifasciata

T. occipitalis

T. rugosus

$\begin{array}{rrrr}1 & & & \\ 2 & 1 & & \\ 1 & & & \\ 4 & 1 & & 4 \\ 14 & 3 & & 3 \\ 8 & & 1 & 2 \\ 10 & & 2 & 12 \\ 35 & 2 & & 5 \\ 10 & 2 & & 1 \\ 9 & 3 & & 10 \\ 39 & 3 & & 1 \\ & & & 3 \\ 6 & 1 & & \end{array}$

910

$\begin{array}{rrr}1 & 3 & 22 \\ 7 & & 7 \\ 13 & 16 & 18 \\ & & 159 \\ & & 20 \\ & & 4 \\ & & 18\end{array}$

Varanus brevicauda

$V$. caudolineatus

$V$. eremius

$V$. gouldii

1
1

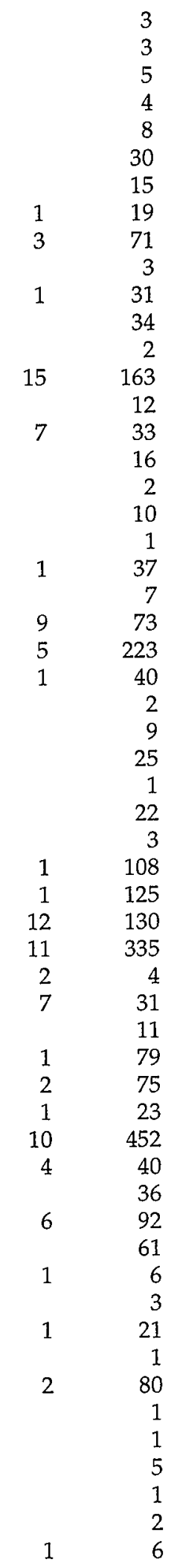

GOANNAS

$\begin{array}{rl}8 & 1 \\ 3 & 1 \\ 29 & 5\end{array}$
2


Tube Bucket

Tube or

Bucket*

SNAKES

Acanthophis pyrrhus

Antaresia perthensis

Brachyurophis. semtifasciatus

Demansia calodera

D. psammophis

Furina ornata

Neelaps bimaclata

Pseudechis australis

Pseudonaja modesta

$P$. nuchalis

Ramphotyphlops australis

R. grypusA

R. grypus B

$R$. hamatus

Simoselaps bertholdi

S. littoralis

Suta fasciata

Totals

2

3

2

Invert Foraging

Not

Specified

Totals

Pit

* Data sheet did not specify whether from tube or bucket. 